\title{
Iron and phosphate uptake explains the calcifuge-calcicole behavior of the terricolous lichens Cladonia furcata subsp. furcata and $C$. rangiformis
}

\author{
Alexander Paul • Markus Hauck • \\ Christoph Leuschner
}

Received: 4 October 2008 / Accepted: 20 November 2008 / Published online: 11 December 2008

(C) The Author(s) 2008. This article is published with open access at Springerlink.com

\begin{abstract}
Mechanisms causing the calcifuge-calcicole behavior of lichens are largely unexplored. Studying the case examples of two closely related terricolous lichens, the calcifuge Cladonia furcata subsp. furcata and the calcicole $C$. rangiformis, we found that preference for acidic or calcareous soils in these lichens is related to iron and phosphate uptake as in vascular plants. In laboratory studies, the calcicole species was more efficient in the intracellular uptake of $\mathrm{Fe}^{3+}$ and phosphate at $\mathrm{pH} 8$ than the calcifuge species. At $\mathrm{pH} \mathrm{3}$, intracellular uptake of $\mathrm{Fe}^{2+}$ in the calcicole species significantly exceeded that in the calcifuge species suggesting that calcicole lichens suffer from toxicity symptoms by excess $\mathrm{Fe}^{2+}$ at acidic sites. Though these observations parallel findings from calcifuge and calcicole vascular plants, mechanisms leading to the different iron and phosphate uptake characteristics in the studied calcifuge and calcicole lichens may differ from those in vascular plants and should be the topic of future research. A role of the depside atranorin in facilitating iron uptake by reducing $\mathrm{Fe}^{3+}$ in the apoplast is hypothesized.
\end{abstract}

Responsible Editor: Ellis Hoffland.

A. Paul $\cdot$ M. Hauck $(\bowtie) \cdot$ C. Leuschner

Department of Plant Ecology, Albrecht von Haller Institute of Plant Sciences, University of Göttingen,

Untere Karspüle 2,

37073 Göttingen, Germany

e-mail: mhauck@gwdg.de
Keywords Lichenized ascomycetes · Acidic soils · Calcareous soils $\cdot$ Iron $\cdot$ Phosphorus

\section{Introduction}

Acidic and calcareous sites strongly differ in their vegetation. This is not only true for vascular plant vegetation, but also applies to lower plants. Only in the case of the vascular plants, however, the mechanisms causing these differences are sufficiently known. Calcifuge vascular plants are excluded from calcareous soils by their lacking ability to fulfill either their $\mathrm{Fe}$ or $\mathrm{P}$ requirements at high $\mathrm{pH}$ (Gries and Runge 1995; Tyler 1996; Zohlen and Tyler 2000). The availability of other transition metals, which are essential micronutrients (including $\mathrm{Cu}, \mathrm{Mn}, \mathrm{Zn}$ ), can also be limiting (Gries et al. 1998). Calcicole plants can, in turn, suffer from high concentrations of transition metals or $\mathrm{Al}$ at acidic sites (Tyler 1993). In lichens, a marked calcifugecalcicole behavior is known for terricolous and saxicolous species (Asta and Lachet 1978; Wirth 1972; Paus 1997). Moreover, epiphyte communities differ between acidic, nutrient-poor substrata and bark surfaces with high concentrations of cations at $\mathrm{pH}$ values around 7 (Barkman 1958).

Despite the similarities between lichens and vascular plants in the existence of calcifuge-calcicole behavior, the element uptake is principally different between these groups of organisms. While mineral 
uptake in vascular plants is generally limited to the root systems, lichens take up substances from the environment through the entire surface. Moreover, lichens use different element sources (Nash 2008). Aside from the soil or other substrates, minerals are taken up from atmospheric sources, including precipitation and the gaseous phase. A typical character of lichens is their ability to store large amounts of cations in the apoplast that can be taken up intracellularly with delay (Hauck et al. 2006). Cation-binding sites in the cell wall (Paul et al. 2003) and lichen secondary metabolites (Hauck et al. 2009) are apparently involved in this process.

Ecophysiological studies that would explain the calcifuge-calcicole behavior of lichens are virtually absent. Pintaric and Türk (1995) showed that lichens from calcareous sites generally contain significantly more $\mathrm{Ca}$ and $\mathrm{Mg}$ than lichens growing on acidic substrata. Fletcher (1976) studying the ecology of coastal saxicolous lichens suggested that the high $\mathrm{Ca}$ content of sea water, rather than the Na content, would be crucial for the zonation of lichen vegetation at sea shores. In his experiments, Fletcher (1976) found that the calcifuge lichen Parmelia saxatilis retained $\mathrm{Ca}$ and $\mathrm{Mg}$ more efficiently than the calcicole Xanthoria parietina, when thalli were rinsed with deionized water. Armstrong (1990, 1993) transplanted lichens from calcareous substrata on siliceous rock and, vice versa, lichens from acidic substrata on artificial limerich materials (cement, asbestos). The calcifuge lichens Parmelia saxatilis and Xanthoparmelia conspersa increased in size 15 months after transplantation to granite or slate, but died on lime. The calcicole lichens Physcia tenella and Xanthoria parietina could only grow on lime (Armstrong 1993), though the latter survived on slate if a paste of $\mathrm{CaCO}_{3}$ or $\mathrm{MgCO}_{3}$ was applied (Armstrong 1990). This effect depended on the anion, and thus evidently on $\mathrm{pH}$, as $\mathrm{CaCl}_{2}$ had no such positive effect on X. parietina (Armstrong 1990).

In the present study, we compared two closely related fruticose, terricolous lichens of the section Ascyphiferae (Stenroos et al. 2002) of the genus Cladonia with each other. C. furcata subsp. furcata grows on acidic soils in patchy grasslands or on siliceous rock outcrops, whereas the morphologically similar C. rangiformis prefers calcareous soils (Purvis et al. 1992; Wirth 1995). The two taxa were chosen for the study, because of their close systematic relationship, their morphological similarities, but their marked differences for acidic versus calcareous soils. By soaking thalli of these species with solutions containing bivalent and trivalent iron or phosphate under acidic $(\mathrm{pH} \mathrm{3})$ or alkaline $(\mathrm{pH} 8)$ conditions in the laboratory, we tested the hypothesis that the calcicole $C$. rangiformis is more efficient in the uptake of $\mathrm{Fe}$ and $\mathrm{P}$ than the calcifuge $C$. furcata subsp. furcata both under acidic and alkaline conditions. Verification of this hypothesis would imply that similar mechanisms could cause the calcifugecalcicole behavior of lichens and vascular plants.

\section{Materials and methods}

Study species

C. furcata (Huds.) Schrad. subsp. furcata and $C$. rangiformis Hoffm. are two closely related members of the fruticose genus Cladonia with erect, dichotomously branched, corticated, hollow thalli (podetia) occasionally scattered with squamules. Morphologically $C$. rangiformis differs by more richly branching and the more areolated cortex from C. furcata subsp. furcata (Purvis et al. 1992; Wirth 1995). Both lichens have a rich secondary chemistry, including the depsidone fumarprotocetraric acid as the most common lichen substance in C. furcata subsp. furcata and atranorin as the most common compound in $C$. rangiformis (Huneck et al. 2004). The fatty acids rangiformic and norrangiformic acids are more frequent in C. rangiformis than in C. furcata subsp. furcata. Except for the fatty acid bourgeanic acid, which is only known from the latter species, all lichen substances generally occur in both species, but in different concentrations (Huneck et al. 2004). Samples used in the experiment were collected in Hesse, Germany (C. furcata: Hombressen, $10 \mathrm{~km} \mathrm{NW}$ Eschwege, $51^{\circ} 30^{\prime} \mathrm{N}, 9^{\circ} 28 \mathrm{E} ; C$. rangiformis:

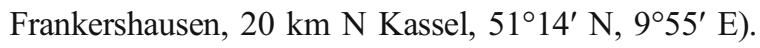
It is important to note that $C$. furcata is used in the sense of $C$. furcata subsp. furcata throughout the paper, as C. furcata subsp. subrangiformis prefers calcareous soils (Wirth 1995).

Experimental details

Lichens were stored in air-dry condition at a temperature of $-18^{\circ} \mathrm{C}$ in the dark before the experiment. 
Freezing is not harmful to dry lichen thalli and is routinely applied in our work group for storing lichens prior to experiments. After unfreezing, thalli of $C$. furcata and C. rangiformis of 2-3 cm length were put on Petri dishes with moist cellulose filters. The thallus base, soil particles and contaminant plant material were carefully removed. Five thalli were put on each Petri dish; each five of these dishes served as replicates. The lichen dry weight of these replicates amounted to $301 \pm 14 \mathrm{mg}(N=40)$ in the sparsely branched C. furcata and $698 \pm 18 \mathrm{mg}$ in the more densely branched $C$. rangiformis. The Petri dishes were stored for 2 days at $80 \%$ relative humidity, a day temperature (for $13 \mathrm{~h}$ daily) of $13^{\circ} \mathrm{C}$ during a photon flux of $30 \mu \mathrm{mol} \mathrm{m} \mathrm{m}^{-2} \mathrm{~s}^{-1}$, and a night temperature of $10^{\circ} \mathrm{C}$ in the growth chamber for acclimatization. Lichen samples were then exposed for $1 \mathrm{~h}$ to $30 \mathrm{~mL}$ of salt solution or to a control of deionized water on a shaker. Metal solutions included $\mathrm{FeCl}_{2}, \mathrm{FeCl}_{3}$, and $\mathrm{KH}_{2} \mathrm{PO}_{4}$ adjusted with $\mathrm{HCl}$ and $\mathrm{NaOH}$ to $\mathrm{pH} 3$ or 8 . The activities of the $\mathrm{Fe}^{2+}, \mathrm{Fe}^{3+}$ or $\mathrm{H}_{2} \mathrm{PO}_{4}{ }^{-}$ions in the solutions amounted to $2 \mathrm{mM}$. Calculations of activities were carried out with the software PHREEQC 2.0 (U.S. Geological Survey, Reston, Virginia, USA). Following the Henderson-Hasselbalch equation, the ratio of $\mathrm{H}_{2} \mathrm{PO}_{4}{ }^{-}$to $\mathrm{PO}_{4}{ }^{3-}$ amounted to 13,490 at $\mathrm{pH} 3$, whereas the $\mathrm{PO}_{4}{ }^{3-}$ ion preponderated at $\mathrm{pH} 8$ with a ratio to $\mathrm{H}_{2} \mathrm{PO}_{4}{ }^{-}$of 7.4. In the following, we refer to $\mathrm{H}_{2} \mathrm{PO}_{4}{ }^{-}$and $\mathrm{PO}_{4}{ }^{3-}$ as phosphate irrespective of the degree of dissociation.

Viability of lichen thalli was controlled by measuring the chlorophyll fluorescence yield $\left(\Phi_{2}\right)$ of the light-adapted samples at photosystem II prior to and after the exposure to the test solutions with a PAM2100 chlorophyll fluorometer (Walz, Effeltrich, Germany). Two measurements were made per replicate. $\Phi_{2}$ stayed invariably in a range between 0.64 and 0.69 , irrespective of the treatment or the point in time, and the values are, thus, not displayed in the results section.

After the exposure to iron, phosphate or water, extra- and intra-cellular cations were sequentially extracted (Brown and Brown 1991; Hauck et al. 2002). For this purpose, samples were shaken twice with $30 \mathrm{~mL}$ of deionized water to remove free apoplastic ions. These water samples were not analyzed. Metal ions bound to hydroxylic or carboxylic exchange sites of the cell wall were exchanged by shaking samples twice each for 20 min with $30 \mathrm{~mL}$
$20 \mathrm{mM} \mathrm{NiCl} 2$. The two $\mathrm{NiCl}_{2}$ solutions per sample were filtered with ash-free filters (Blue Ribbon Filters, Whatman-Schleicher \& Schuell, Dassel, Germany) and pooled for analysis. Afterwards, samples were dried at $105^{\circ} \mathrm{C}$, homogenized, and digested with $65 \% \mathrm{HNO}_{3}$ in order to determine the intracellular ions. Total concentrations of $\mathrm{Fe}, \mathrm{P}$ and additionally $\mathrm{K}, \mathrm{Ca}$, and $\mathrm{Mg}$ in the $\mathrm{NiCl}_{2}$ solutions and acid digests were determined with inductively coupled plasma atomic emission spectroscopy (ICP-AES, Spectraflame, Spectro Analytical Instruments, Fitchburg, Massachusetts, USA). A quantitative release of phosphate from the apoplast by the $\mathrm{Cl}^{-}$ions of the $\mathrm{NiCl}_{2}$ solution was not be expected despite the high concentration of the $\mathrm{NiCl}_{2}$ solution, because $\mathrm{Cl}^{-}$is a weak competitor for potential cationic binding sites in the apoplast. Therefore, $\mathrm{P}$ concentrations of $\mathrm{NiCl}_{2}$ and $\mathrm{HNO}_{3}$ fractions were summated to a total $\mathrm{P}$ concentration.

\section{Statistics}

All data are given as arithmetic means \pm standard error and were tested for normal distribution with the Shapiro-Wilk test. Samples were tested with Duncan's multiple range test for the comparison of more than two means. Statistical analyses were calculated with SAS 6.04 software (SAS Institute Inc., Cary, North Carolina, USA).

\section{Results}

Iron uptake

Thalli of C. furcata subsp. furcata and C. rangiformis not exposed to iron chloride solution did not differ in their Fe content (Table 1). From the cation exchange sites in the apoplast of these thalli, Fe was virtually absent (Table 2). Intracellular uptake of $\mathrm{Fe}^{2+}$ was significantly higher in the calcicole $C$. rangiformis than in the calcifuge C. furcata at $\mathrm{pH} 3$ (Table 1). At pH 8, no significant differences occurred in the intracellular $\mathrm{Fe}^{2+}$ uptake between these lichen species (Table 1). Extracellular $\mathrm{Fe}^{2+}$ adsorption was indifferent to $\mathrm{pH}$ in C. furcata and generally higher than in C. rangiformis (Table 2). In C. rangiformis, extracellular $\mathrm{Fe}^{2+}$ adsorption was negligible at $\mathrm{pH} 8$, but occurred at $\mathrm{pH} 3$ (Table 2). Intracellular $\mathrm{Fe}^{3+}$ uptake took place in both species, but was significantly higher in C. rangiformis 
Table 1 Concentrations of intracellular $\mathrm{Fe}, \mathrm{K}, \mathrm{Ca}$ and $\mathrm{Mg}$ (in $\mu \mathrm{mol} \mathrm{g}{ }^{-1}$ dry weight) in C. furcata and C. rangiformis after soaking with deionized water, $\mathrm{FeCl}_{2}$, or $\mathrm{FeCl}_{3}(a=2 \mathrm{mM})$ at $\mathrm{pH} 3$ or 8 for $1 \mathrm{~h}$

\begin{tabular}{|c|c|c|c|c|}
\hline & \multicolumn{2}{|l|}{$\mathrm{pH} 3$} & \multicolumn{2}{|l|}{ pH 8} \\
\hline & C. furcata & C. rangiformis & C. furcata & C. rangiformis \\
\hline \multicolumn{5}{|c|}{ Control } \\
\hline $\mathrm{Fe}$ & $5.7 \pm 0.7 \mathrm{a}^{\mathrm{a}}$ & $6.4 \pm 0.6 \mathrm{a}$ & $7.0 \pm 0.6 \mathrm{a}$ & $4.1 \pm 0.3 \mathrm{a}$ \\
\hline K & $56.0 \pm 5.9 \mathrm{a}$ & $24.8 \pm 2.0 \mathrm{bd}$ & $46.3 \pm 5.0 \mathrm{c}$ & $28.2 \pm 1.8 \mathrm{bd}$ \\
\hline $\mathrm{Ca}$ & $3.5 \pm 0.4 \mathrm{a}$ & $107 \pm 14 \mathrm{bc}$ & $3.8 \pm 0.3 \mathrm{a}$ & $79.5 \pm 7.7 \mathrm{~b}$ \\
\hline $\mathrm{Mg}$ & $7.4 \pm 0.6 \mathrm{ab}$ & $15.8 \pm 3.2 \mathrm{c}$ & $6.7 \pm 0.4 \mathrm{a}$ & $14.0 \pm 1.6 \mathrm{c}$ \\
\hline \multicolumn{5}{|c|}{$\mathrm{FeCl}_{2}$} \\
\hline $\mathrm{Fe}$ & $13.7 \pm 1.2 \mathrm{a}$ & $43.5 \pm 2.7 \mathrm{~b}$ & $39.7 \pm 4.2 \mathrm{bc}$ & $31.3 \pm 1.4 \mathrm{c}$ \\
\hline $\mathrm{K}$ & $34.4 \pm 4.3 \mathrm{de}$ & $23.5 \pm 0.8 \mathrm{~b}$ & $48.1 \pm 2.1 \mathrm{ac}$ & $30.3 \pm 0.7 \mathrm{bd}$ \\
\hline $\mathrm{Ca}$ & $3.1 \pm 0.1 \mathrm{a}$ & $129 \pm 34 \mathrm{c}$ & $3.2 \pm 0.4 \mathrm{a}$ & $97.5 \pm 16.4 \mathrm{bc}$ \\
\hline $\mathrm{Mg}$ & $5.1 \pm 0.7 \mathrm{a}$ & $13.1 \pm 2.1 \mathrm{bc}$ & $6.4 \pm 0.2 \mathrm{a}$ & $13.6 \pm 3.3 \mathrm{c}$ \\
\hline \multicolumn{5}{|c|}{$\mathrm{FeCl}_{3}$} \\
\hline $\mathrm{Fe}$ & $43.5 \pm 1.9 \mathrm{~b}$ & $59.1 \pm 4.4 \mathrm{~d}$ & $53.4 \pm 5.9 \mathrm{~d}$ & $68.9 \pm 4.0 \mathrm{e}$ \\
\hline $\mathrm{K}$ & $27.8 \pm 1.6 \mathrm{bd}$ & $21.6 \pm 0.8 \mathrm{~b}$ & $43.5 \pm 5.2 \mathrm{ce}$ & $29.8 \pm 0.6 \mathrm{bd}$ \\
\hline $\mathrm{Ca}$ & $2.4 \pm 0.3 \mathrm{a}$ & $105 \pm 14 \mathrm{bc}$ & $3.4 \pm 0.4 \mathrm{a}$ & $111 \pm 27 \mathrm{bc}$ \\
\hline $\mathrm{Mg}$ & $5.4 \pm 0.3 \mathrm{a}$ & $10.8 \pm 1.4 \mathrm{abc}$ & $6.1 \pm 0.6 \mathrm{a}$ & $13.1 \pm 3.2 \mathrm{bc}$ \\
\hline
\end{tabular}

Control

${ }^{\text {a }}$ For a given metal, means $( \pm$ SE) followed by equal letters do not differ significantly (Duncan's multiple range test, $P \leq 0.05, d f=48$ )

than C. furcata (Table 1). Notable amounts of extracellularly bound $\mathrm{Fe}^{3+}$ were found in both species at $\mathrm{pH} \mathrm{3}$, but not at $\mathrm{pH} 8$ (Table 2). The content of extracellular $\mathrm{Fe}^{3+}$ at $\mathrm{pH} 3$ was even higher in $C$. furcata than C. rangiformis (Table 2).

Uptake of $\mathrm{Fe}^{2+}$ or $\mathrm{Fe}^{3+}$ had no influence on intracellular $\mathrm{K}, \mathrm{Ca}$ or $\mathrm{Mg}$ concentrations (Table 1). Intracellular $\mathrm{Ca}$ and $\mathrm{Mg}$ concentrations were generally much higher in $C$. rangiformis than $C$. furcata (Table 2). Ca concentrations were 20 to 40 times higher in the former than the latter species. Intracellular $\mathrm{Mg}$ concentrations in C. rangiformis exceeded those in C. furcata by the factor 2 or higher. Lower $\mathrm{Ca}$ and $\mathrm{Mg}$ concentrations in the cells of $C$. furcata were compensated by higher $\mathrm{K}$ concentrations, though they only differed between the species by the factor 2 in the

Table 2 Concentrations of $\mathrm{Fe}, \mathrm{K}, \mathrm{Ca}$ and $\mathrm{Mg}$ (in $\mu \mathrm{mol} \mathrm{g}^{-1}$ dry weight) bound to extracellular exchange sites in $C$. furcata and $C$. rangiformis after soaking with deionized water, $\mathrm{FeCl}_{2}$, or $\mathrm{FeCl}_{3}(a=2 \mathrm{mM})$ at $\mathrm{pH} 3$ or 8 for $1 \mathrm{~h}$

\begin{tabular}{|c|c|c|c|c|}
\hline & \multicolumn{2}{|l|}{$\mathrm{pH} 3$} & \multicolumn{2}{|l|}{ pH 8} \\
\hline & C. furcata & C. rangiformis & C. furcata & C. rangiformis \\
\hline \multicolumn{5}{|c|}{ Control } \\
\hline $\mathrm{Fe}$ & $0.0 \pm 0.0 \mathrm{a}^{\mathrm{a}}$ & $0.0 \pm 0.0 \mathrm{a}$ & $0.0 \pm 0.0 \mathrm{a}$ & $0.0 \pm 0.0 \mathrm{a}$ \\
\hline $\mathrm{Ca}$ & $11.8 \pm 1.0 \mathrm{a}$ & $62.8 \pm 3.8 \mathrm{~b}$ & $23.8 \pm 2.1 \mathrm{c}$ & $66.3 \pm 2.2 \mathrm{~b}$ \\
\hline $\mathrm{Mg}$ & $2.4 \pm 0.2 \mathrm{a}$ & $39.8 \pm 2.2 \mathrm{~b}$ & $5.7 \pm 0.3 \mathrm{a}$ & $45.8 \pm 3.3 \mathrm{c}$ \\
\hline \multicolumn{5}{|c|}{$\mathrm{FeCl}_{2}$} \\
\hline $\mathrm{Fe}$ & $8.5 \pm 0.7 \mathrm{~b}$ & $5.8 \pm 0.6 \mathrm{c}$ & $7.6 \pm 0.4 \mathrm{~b}$ & $0.1 \pm 0.0 \mathrm{a}$ \\
\hline $\mathrm{Ca}$ & $6.2 \pm 0.4$ ae & $42.2 \pm 2.4 \mathrm{~d}$ & $9.2 \pm 0.7$ ae & $60.8 \pm 2.7 \mathrm{~b}$ \\
\hline $\mathrm{Mg}$ & $1.5 \pm 0.1 \mathrm{a}$ & $20.0 \pm 1.9 \mathrm{~d}$ & $2.0 \pm 0.2 \mathrm{a}$ & $35.4 \pm 1.7 \mathrm{e}$ \\
\hline \multicolumn{5}{|c|}{$\mathrm{FeCl}_{3}$} \\
\hline $\mathrm{Fe}$ & $15.0 \pm 0.7 \mathrm{~d}$ & $11.1 \pm 1.3 \mathrm{e}$ & $0.1 \pm 0.0 \mathrm{a}$ & $0.1 \pm 0.0 \mathrm{a}$ \\
\hline $\mathrm{Ca}$ & $4.4 \pm 0.2 \mathrm{e}$ & $26.0 \pm 2.0 \mathrm{c}$ & $7.6 \pm 0.6$ ae & $35.4 \pm 4.1 \mathrm{f}$ \\
\hline $\mathrm{Mg}$ & $1.2 \pm 0.1 \mathrm{a}$ & $13.3 \pm 1.4 \mathrm{f}$ & $1.6 \pm 0.2 \mathrm{a}$ & $14.5 \pm 1.4 \mathrm{f}$ \\
\hline
\end{tabular}

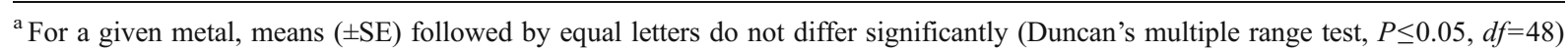


controls and even less after Fe uptake (Table 2). In both species, concentrations of $\mathrm{Ca}$ and $\mathrm{Mg}$ bound to extracellular exchange sites were moderately to appreciably reduced by $\mathrm{Fe}^{2+}$ and $\mathrm{Fe}^{3+}$ uptake in most treatments, though the differences were only partly significant (Table 2). However, $\mathrm{Fe}^{2+}$ uptake in $C$. rangiformis did not affect the extracellular $\mathrm{Ca}$ concentrations at $\mathrm{pH} 8$ (Table 2). Extracellular $\mathrm{K}$ concentrations are not included in Table 2, because they are highly variable due to the low affinity of the $\mathrm{K}^{+}$ion to carboxylic and hydroxylic moieties and thus little informative.

\section{Phosphate uptake}

In the controls, the total $\mathrm{P}$ content in C. furcata exceeded that in $C$. rangiformis approximately by the factor 1.5 irrespective of $\mathrm{pH}$ (Fig. 1a). At $\mathrm{pH} \mathrm{3}$, the efficacy of phosphate uptake did not differ between the species, as the total $\mathrm{P}$ content doubled during the treatment with $\mathrm{KH}_{2} \mathrm{PO}_{4}$ in spite of the different initial concentrations (Fig. 1b). At $\mathrm{pH} \mathrm{8}$, the two lichens responded very differently to the exposure to phosphate: uptake was much more efficient in $C$. rangiformis, where the phosphate concentration increased by the factor 2.6, than in C. furcata, where the concentration merely increased by the factor 1.3 (Fig. 1b).

\section{Discussion}

Efficient intracellular $\mathrm{Fe}^{3+}$ and phosphate uptake qualifies $C$. rangiformis for the colonization of calcareous soils. The uptake of $\mathrm{Fe}^{2+}$ in $C$. rangiformis was relatively inefficient at $\mathrm{pH} 8$, but this is of subordinate significance, as $\mathrm{Fe}^{3+}$ is prevailing under alkaline conditions. In $C$. furcata subsp. furcata, uptake of $\mathrm{Fe}^{3+}$ at $\mathrm{pH} 8$ was significantly lower than in $C$. rangiformis and uptake of phosphate was nearly absent. This explains that $C$. furcata avoids calcareous soils. Much more efficient uptake of $\mathrm{Fe}^{2+}$ under acidic conditions in the calcicole $C$. rangiformis than in the calcifuge $C$. furcata explains the avoidance of acidic soils by $C$. rangiformis. $\mathrm{Fe}^{2+}$ is the prevalent form of iron under acidic conditions. The uptake of $\mathrm{Fe}^{2+}$ in $C$. rangiformis exceeded that in $C$. furcata by the factor 3.2 at $\mathrm{pH} 3$, whereas the uptake of $\mathrm{Fe}^{3+}$ was only $1.3-$ times higher in C. rangiformis than C. furcata. Excess

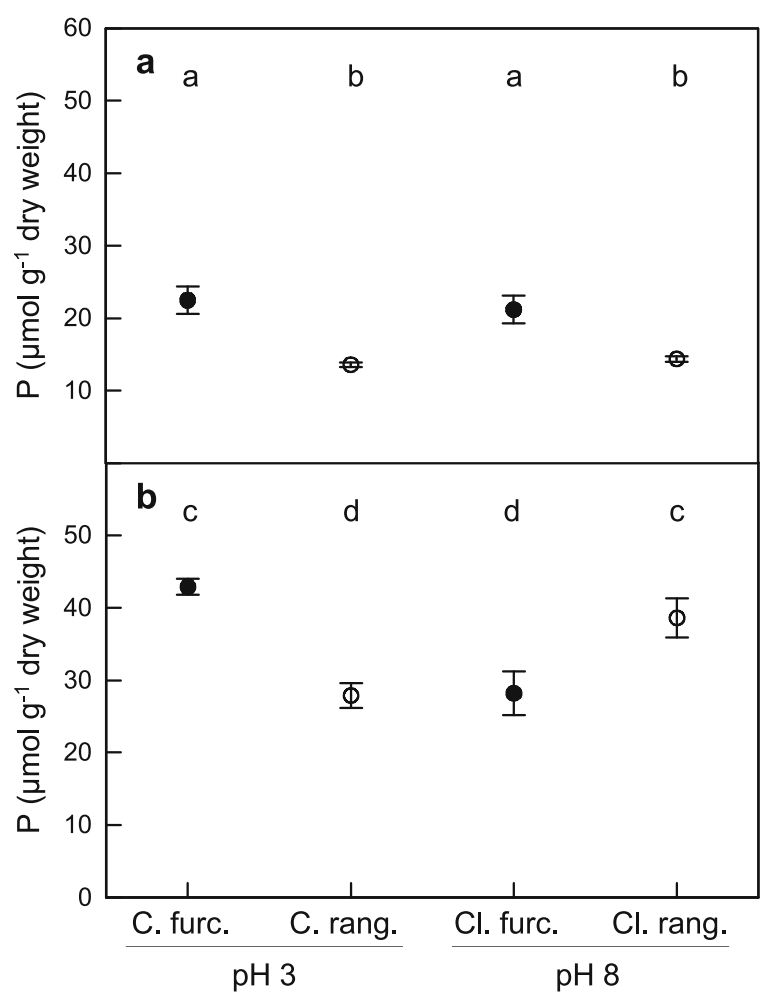

Fig. 1 Total $\mathrm{P}$ concentrations of Cladonia furcata or $C$. rangiformis exposed for $1 \mathrm{~h}$ min to a deionized water or $\mathbf{b}$ $\mathrm{KH}_{2} \mathrm{PO}_{4}(a=2 \mathrm{mM})$ at $\mathrm{pH} 3$ or 8 . Means $( \pm \mathrm{SE})$ annotated with equal letters do not differ significantly (one common Duncan's multiple range test for data displayed in $\mathbf{a}-\mathbf{b} ; P \leq 0.05, d f=32$ )

amounts both of $\mathrm{Fe}^{2+}$ and $\mathrm{Fe}^{3+}$ are known to cause chlorophyll degradation in lichens (Garty et al. 1992; Hauck et al. 2003).

As to be expected, our results agree with those of Pintaric and Türk (1995) that calcicole lichens contain considerably more $\mathrm{Ca}$ and $\mathrm{Mg}$ than calcifuge lichens. However, we could not confirm the hypothesis of Fletcher (1976) that calcifuge lichens would release their $\mathrm{Ca}$ and $\mathrm{Mg}$ less readily in exchange for other ions than calcicole lichens. Low intracellular concentrations of $\mathrm{Ca}$ and $\mathrm{Mg}$ in the calcifuge $C$. furcata were compensated by the accumulation of $\mathrm{K}$ (Table 1).

Our results suggest that, as in higher plants, $\mathrm{Fe}$ and P shortages exclude calcifuge lichens from calcareous soils and $\mathrm{Fe}$ hyperaccumulation excludes calcicole lichens from acidic sites. Whether the limited availability of essential transition metals other than Fe, including $\mathrm{Cu}, \mathrm{Mn}$ and $\mathrm{Zn}$ (Gries et al. 1998), plays an 
additional role at excluding calcifuge lichens from alkaline calcareous soils has still to be investigated. The same is true for the accumulation of potentially toxic amounts of $\mathrm{Cu}, \mathrm{Mn}$ or $\mathrm{Zn}$ by calcicole lichens at acidic sites. It is plausible to assume that relations in saxicolous lichens are similar to those than in terricolous lichens. The extent of parallels to factors controlling the distribution of epiphytic lichens on acidic versus mineral-rich bark should be studied, because the least acidic bark is usually still slightly acidic (around pH 6) to neutral (Wirth 1995).

Despite the common significance of $\mathrm{Fe}$ and $\mathrm{P}$ in the control of $\mathrm{pH}$ preferences both in vascular plants and lichens, mechanisms causing the differences in the $\mathrm{Fe}$ and $\mathrm{P}$ uptake between calcifuge and calcicole species are likely to be quite different between vascular plants and lichens. Mechanisms of Fe and P uptake in lichens are still largely unexplored. High efficiency of phosphate uptake was demonstrated in two acidophytic lichens under acidic conditions (Farrar 1976; Hyvärinen and Crittenden 1998). Promotion of phosphate uptake in calcicole lichens by the exudation of low-molecular organic acids as in vascular plants (Ström et al. 1994; Tyler and Ström 1995; Zohlen and Tyler 2004) is conceivable, because the release of oxalate from lichens is known in the context of extracellular metal binding (Wilson and Jones 1984). Any involvement in the uptake of phosphate in lichens has not been investigated, though.

Parallels in increasing the uptake of $\mathrm{Fe}$ under alkaline conditions between vascular plants and lichens are perhaps limited. Vascular plants respond to $\mathrm{Fe}$ deficiency on calcareous soils with increased root formation, $\mathrm{H}^{+}$extrusion, increased reductase activity, or the production of phytosiderophores (Marschner et al. 1986; Römheld 1987; Von Wirén et al. 2000). The increase of the absorbing surfaces, analogously to increased root growth, is improbable to be realized in the slow-growing lichens lacking any root system. In contrast to vascular plants, the ability for intracellular uptake of $\mathrm{Fe}^{3+}$ by ferric permeases or siderophore permeases is apparently widespread in fungi (Kosman 2003; Eichhorn et al. 2006). The recent discovery that phenolic lichen substances are involved in the metal homeostasis of lichens (Hauck 2008) suggests that lichen substances could also facilitate the acquisition of $\mathrm{Fe}$ at high $\mathrm{pH}$. This hypothesis was already published by Engstrom et al. (1980), but has never been scrutinized. A plausible mechanism not yet discussed would be facilitation of $\mathrm{Fe}^{3+}$ uptake by using the reductive power of phenolic lichen substances analogously to caffeic acid in vascular plants. Caffeic acid promotes Fe uptake by supplying electrons for the extracellular reduction of $\mathrm{Fe}^{3+}$ to $\mathrm{Fe}^{2+}$ (Römheld and Marschner 1983; Deiana et al. 1995). The cortical depside atranorin, being a major lichen substance of the calcicole Cladonia rangiformis (Huneck et al. 2004), would be a favorite for a putatively $\mathrm{Fe}^{3+}$-reducing lichen substance, because it functions, like caffeic acid (Lafay et al. 2005), as a strong antioxidant (Valencia-Islas et al. 2007). Remarkably, atranorin, which is rare in the calcifuge C. furcata subsp. furcata, is also a major secondary metabolite of the calcicole $C$. furcata subsp. subrangiformis (Wirth 1995).

\section{Conclusions}

Our results from the calcifuge $C$. furcata and the calcicole $C$. rangiformis suggest that $\mathrm{Fe}$ and/or phosphate uptake are, like in vascular plants, the key factor determining the preference of lichens for acidic and calcareous sites. Mechanisms causing the different efficacies of $\mathrm{Fe}$ and phosphate uptake at different $\mathrm{pH}$ in C. furcata and C. rangiformis or other calcifuge versus calcicole lichens are still unexplored. The present study is the first one substantiating the significance of $\mathrm{Fe}$ and $\mathrm{P}$ uptake for the calcifugecalcicole behavior of lichens.

Acknowledgments The study was funded by a grant of the Deutsche Forschungsgemeinschaft (DFG Pa 1544/1-1). ICP analyses were carried out at the Institute of Soil Science and Forest Nutrition (Dr. N. Lamersdorf) at the University of Göttingen. We are thankful to Prof. Dr. G. Tyler (Dept. Ecology, University of Lund, Sweden) and an unknown reviewer for helpful comments to the manuscript.

Open Access This article is distributed under the terms of the Creative Commons Attribution Noncommercial License which permits any noncommercial use, distribution, and reproduction in any medium, provided the original author(s) and source are credited.

\section{References}

Armstrong RA (1990) The influence of calcium and magnesium on the growth of the lichens Parmelia saxatilis and Xanthoria parietina on slate substrates. Environ Exp Bot 30:51-57, doi:10.1016/0098-8472(90)90008-R 
Armstrong RA (1993) The growth of six saxicolous lichens transplanted to lime-rich and lime-poor substrates in South Gwynedd, Wales. Symbiosis 15:257-267

Asta J, Lachet B (1978) Analyses des relations entre la teneur en carbonate de calcium des substrats et divers groupements phytosociologiques de lichens saxicoles. Oecol Plant 13:193-206

Barkman JJ (1958) Phytosociology and ecology of cryptogamic epiphytes. Van Gorcum, Assen

Brown DH, Brown RM (1991) Mineral cycling and lichens: the physiological basis. Lichenologist 23:293-307

Deiana S, Gessa C, Marchetti M, Usai M (1995) Phenolic acid redox properties: $\mathrm{pH}$ influence on iron(III) reduction by caffeic acid. Soil Sci Soc Am J 59:1301-1307

Eichhorn H, Lessing F, Winterberg B, Schirawski J, Kämper J, Müller P, Kahmann R (2006) A ferroxidation/permeation iron uptake system is required for virulence in Ustilago maydis. Plant Cell 18:3332-3345, doi:10.1105/tpc.106.043588

Engstrom GW, McDorman DJ, Maroney MJ (1980) Iron chelating capability of physcion from Aspergillus ruber. J Agric Food Chem 28:1139-1141, doi:10.1021/jf60232a017

Farrar JF (1976) The uptake and metabolism of phosphate by the lichen Hypogymnia physodes. New Phytol 77:127134, doi:10.1111/j.1469-8137.1976.tb01506.x

Fletcher A (1976) Nutritional aspects of marine and maritime lichen ecology. In: Brown DH, Hawksworth DL, Bailey RH (eds) Lichenology: progress and problems. Academic, London, pp 359-384

Garty J, Karary Y, Harel J (1992) Effect of low pH, heavy metals and anions on chlorophyll degradation in the lichen Ramalina duriaei (De Not.) Bagl. Environ Exp Bot 32:229-241, doi:10.1016/0098-8472(92)90006-N

Gries D, Runge M (1995) Responses of calcicole and calcifuge Poaceae species to iron-limiting conditions. Bot Acta 108:482-489

Gries D, Klatt S, Runge M (1998) Copper-deficiency-induced phytosiderophore release in the calcicole grass Hordelymus europaeus. New Phytol 140:95-101, doi:10.1046/ j.1469-8137.1998.00250.x

Hauck M (2008) Metal homeostasis in Hypogymnia physodes is controlled by lichen substances. Environ Pollut 153:304308, doi:10.1016/j.envpol.2007.08.023

Hauck M, Mulack C, Paul A (2002) Manganese uptake in the epiphytic lichens Hypogymnia physodes and Lecanora conizaeoides. Environ Exp Bot 48:107-116, doi:10.1016/ S0098-8472(02)00014-X

Hauck M, Paul A, Gross S, Raubuch M (2003) Manganese toxicity in epiphytic lichens: chlorophyll degradation and interaction with iron and phosphorus. Environ Exp Bot 49:181-191, doi:10.1016/S0098-8472(02)00069-2

Hauck M, Paul A, Spribille T (2006) Uptake and toxicity of manganese in epiphytic cyanolichens. Environ Exp Bot 56:216-224, doi:10.1016/j.envexpbot.2005.02.005

Hauck M, Jürgens S-R, Willenbruch K, Huneck S, Leuschner C (2009) Dissociation and metal-binding characteristics of yellow lichen substances suggest a relationship with site preferences of lichens. Ann Bot (Lond) (in press)

Huneck S, Feige GB, Schmidt J (2004) Chemie von Cladonia furcata und Cladonia rangiformis. Herzogia 17:51-58

Hyvärinen M, Crittenden PD (1998) Phosphate uptake in Cladonia portentosa. Lichenologist 30:297-301
Kosman DJ (2003) Molecular mechanisms of iron uptake in fungi. Mol Microbiol 47:1185-1197, doi:10.1046/j.13652958.2003.03368.x

Lafay S, Gueux E, Rayssiguier Y, Mazur A, Rémésy C, Scalbert A (2005) Caffeic acid inhibits oxidative stress and reduces hypercholesterolemia induced by iron overload in rats. Int J Vitam Nutr Res 75:119-125, doi:10.1024/03009831.75.2.119

Marschner H, Römheld V, Kissel M (1986) Different strategies in higher plants in mobilization and uptake of iron. J Plant Nutr 9:695-713

Nash TH (2008) Nutrients, elemental accumulation, and mineral cycling. In: Nash TH (ed) Lichen biology, 2nd edn. Cambridge University Press, Cambridge, pp 234-251

Paul A, Hauck M, Fritz E (2003) Effects of manganese on element distribution and structure in thalli of the epiphytic lichens Hypogymnia physodes and Lecanora conizaeoides. Environ Exp Bot 50:113-124, doi:10.1016/ S0098-8472(03)00017-0

Paus S (1997) Die Erdflechtenvegetation Nordwestdeutschlands und einiger Randgebiete. Vegetationsökologische Untersuchungen unter besonderer Berücksichtigung des Chemismus ausgewählter Arten. Bibl Lichenol 66:1222

Pintaric M, Türk R (1995) Vergleichende Untersuchungen über den $\mathrm{Ca}-\mathrm{Mg}$ - und $\mathrm{K}-\mathrm{Gehalt}$ von Flechten und ihrem Substrat von Kalk- und Silikatstandorten. Bibl Lichenol 57:363-385

Purvis OW, Coppins BJ, Hawksworth DL, James PW, Moore DM (eds) (1992) The lichen flora of Great Britain and Ireland. British Museum of Natural History, London

Römheld V (1987) Different strategies for iron acquisition in higher plants. Physiol Plant 70:231-234, doi:10.1111/ j.1399-3054.1987.tb06137.x

Römheld V, Marschner H (1983) Mechanism of iron uptake by peanut plants. Plant Physiol 71:949-954

Stenroos S, Hyvönen J, Myllys L, Thell A, Ahti T (2002) Phylogeny of the genus Cladonia s.lat. (Cladoniaceae, Ascomycetes) inferred from molecular, morphological, and chemical data. Cladistics 18:237-278, doi:10.1111/ j.1096-0031.2002.tb00151.x

Ström L, Olsson T, Tyler G (1994) Differences between calcifuge and acidifuge plants in root exudation of lowmolecular organic acids. Plant Soil 167:239-245, doi:10.1007/BF00007950

Tyler G (1993) Soil solution chemistry controlling the field distribution of Melica ciliata L. Ann Bot (Lond) 71:295301, doi:10.1006/anbo.1993.1038

Tyler G (1996) Soil chemical limitations to growth and development of Veronica officinalis L. and Carex pilulifera L. Plant Soil 184:281-289, doi:10.1007/ BF00010457

Tyler G, Ström L (1995) Differing organic acid exudation pattern explains calcifuge and acidifuge behaviour of plants. Ann Bot (Lond) 75:75-78, doi:10.1016/S03057364(05)80011-3

Valencia-Islas N, Zambrano A, Rojas JL (2007) Ozone reactivity and free radical scavenging behavior of phenolic secondary metabolites in lichens exposed to chronic oxidant air pollution from Mexico City. J Chem Ecol 33:1619-1634, doi:10.1007/s10886-007-9330-1 
Von Wirén N, Khodr H, Hider RC (2000) Hydroxylated phytosiderophore species possess an enhanced chelate stability and affinity for iron(III). Plant Physiol 124:1149-1158, doi:10.1104/pp.124.3.1149

Wilson MJ, Jones D (1984) The occurrence and significance of manganese oxalate in Pertusaria corallina (Lichenes). Pedobiologia (Jena) 26:373-379

Wirth V (1972) Die Silikatflechten-Gemeinschaften im außeralpinen Zentraleuropa. Diss Bot 17:1-306
Wirth V (1995) Die Flechten Baden-Württembergs, vol. 1 \& 2, 2nd edn. Ulmer, Stuttgart

Zohlen A, Tyler G (2000) Immobilization of tissue iron on calcareous soil: differences between calcicole and calcifuge plants. Oikos 89:95-106, doi:10.1034/j.16000706.2000.890110.x

Zohlen A, Tyler G (2004) Soluble inorganic tissue phosphorus and calcicole-calcifuge behaviour of plants. Ann Bot (Lond) 94:427-432, doi:10.1093/aob/mch162 